\title{
CHITOSAN ISOLATION AND ITS APPLICATION TO REDUCE THE CONTENT OF METAL IONS IN WELLBORE WATER
}

\author{
Yulida Amri ${ }^{*}$, Rahmatul Fajri' ${ }^{2}$, Matius Stefanus Batu ${ }^{3}$ \\ ${ }^{1,2}$ Department of Chemistry, Faculty of Engineering, Samudra University \\ Jl. Meurandeh Langsa Aceh 24416, Indonesia \\ ${ }^{3}$ Department of Chemistry, Faculty of Agriculture, Timor University \\ Jl. Eltari Kefamenanu NTT 85613, Indonesia
}

Received: $4^{\text {th }}$ September 2019; Revised: $27^{\text {th }}$ September 2019; Accepted: $29^{\text {th }}$ October 2019

\begin{abstract}
Potential water sources such as white shrimp shell waste (Penaeus merguiensis) can be used as a source of chitosan. Chitosan can be applied as an environmentally friendly adsorbent for water treatment because of its ability to adsorb metal ions. In this study, chitosan was isolated through several stages such as demineralization, deproteination, decolourization and deacetylation. The yield of chitosan obtained from this study was $17.73 \%$. Characterization by infrared spectroscopy (FTIR) showed the absorption at 3355 $\mathrm{cm}^{-1}$ indicating the presence of amine $\left(-\mathrm{NH}_{2}\right)$ and hydroxyl $(-\mathrm{OH})$ groups. The absorption of the carbonyl group $(-\mathrm{C}=\mathrm{O})$ at $1642 \mathrm{~cm}^{-1}$ disappeared while the absorption of the free amine group $\left(-\mathrm{NH}_{2}\right)$ at $1590 \mathrm{~cm}^{-}$ ${ }^{1}$ increased indicating the successful deacetylation with a degree of deacetylation (DD) $78 \%$. Application of chitosan in wellbore water did not affect on colour change and decreasing of iron (Fe) content due to low concentration of iron ( $\mathrm{Fe})$. However, chitosan can reduce the $\mathrm{pH}$ value of water and manganese $(\mathrm{Mn})$ content. The results of ANOVA and DMRT test at 0.05 significance level showed that chitosan with various mass had different effects. The more the mass of chitosan added, the higher the content of manganese (Mn) will decrease.
\end{abstract}

Keywords: Chitosan; Iron Ion; Manganese Ion; Wellbore Waters

\section{Introduction}

Kota Langsa is a city located on the east coast of Aceh and has great potential in the fields of tourism, plantation and marine. Kuala Langsa is one of the areas in Kota Langsa which is bordered by the sea so that can be a producer of various marine resources such as fish, oysters, crabs and clams.

Consumption of shrimp by the community will certainly produce waste in the form of shrimp shells. Shrimp shells waste produced from households can be used as a source of chitosan. Generally, chitosan comes from animals that have outer and hard skin such as crabs, shrimp, insects, oyster shells and other marine animals. ${ }^{1}$ Therefore, coastal and marine resources such as white shrimp shells (Penaeus merguiensis) can be used as a potential source of chitosan because they're

\footnotetext{
*Corresponding author.

E-Mail: yulidaamri@unsam.ac.id
}

composed of chitin (20-25\%). There are about $40 \%$ of shrimp weight becomes waste which mainly consists of chitin (20-25\%), pigments, calcium carbonate $(30 \%)$, protein and lipid. ${ }^{2}$ Chitin itself can be transformed into chitosan which has many advantages. Chitosan can function as a membrane and an adsorbent material so that chitosan can be used as a natural adsorbent for water treatment that is environmentally friendly. During this time, synthetic coagulant material has been applied more in the water treatment process. ${ }^{3}$

Kota Langsa also has problems in the provision of clean water. So far, the community has used water supply from Lengkong (Langsa Baro District, Kota Langsa) and PDAM as a source of clean water. However, the community still has complaints related to PDAM water which is still turbid and yellowish. ${ }^{4}$ In addition, some 
other residents use wellbore as a source of water for bathing and washing. Water from the wellbore is generally yellowish and turbid so it must be filtered first. The yellowish and turbid water can be caused by the presence of metals such as iron (Fe) and manganese (Mn). The presence of iron $(\mathrm{Fe})$ and manganese (Mn) content in water causes the colour of the water to turn brownish yellow after some time of contact with air. ${ }^{5}$

In this research, chitosan was isolated from white shrimp shells (Penaeus merguiensis) and then applied as an adsorbent to reduce the content of iron $(\mathrm{Fe})$ and manganese $(\mathrm{Mn})$ in the wellbore water in Paya Bujok Seuleumak, Kota Langsa. Chitosan can be isolated by chemical $^{6}$ and biological method (using bacteria and enzyme). ${ }^{7,8}$ Chemical method involves chemical treatment in room temperature $^{1}$ or high temperature (using conventional heater ${ }^{9}$ or microwave irradiation). ${ }^{10,11}$ Previous studies required a longer time ${ }^{1,9}$ of isolation and produced a low yield $^{9}$ as well as a low degree of deacetylation of chitosan product. ${ }^{1}$ In this study, chitosan was isolated by a modification of reported method $^{9}$ to make isolation process going faster and give higher in yield and degree of deacetylation. This research is expected to overcome problems related to household waste in the form of shrimp shells and water problems with iron $(\mathrm{Fe})$ and manganese $(\mathrm{Mn})$ content in Kota Langsa.

\section{Methods}

\section{Isolation and Characterization of Chitosan}

White shrimp shell waste (Penaeus merguensis) was collected from households. Then washed with water and cleaned. The dried shrimp shell waste was crushed with a blender. Then it was weighed as much as 101.16 grams and put into a $1 \mathrm{~L}$ beaker. For the deproteination process, into shrimp shell powder the solution of $5 \% \mathrm{NaOH}$ has added as much as $750 \mathrm{~mL}$ and heated at $75{ }^{\circ} \mathrm{C}$ for 1 hour. After that, the shrimp shell powder was washed with water until the $\mathrm{pH}$ becomes neutral. The process continued to the demineralization stage by adding $350 \mathrm{~mL} \mathrm{HCl}$ $10 \%(\mathrm{v} / \mathrm{v})$ to shrimp shell powder and heated at $70{ }^{\circ} \mathrm{C}$ for 1 until no more gas bubbles were generated. The shrimp shell powder then was washed and confirmed to be neutral $\mathrm{pH}$ with universal litmus. The decolourization process was carried out by adding $0.4 \%$ (v/v) $\mathrm{NaOCl}$ as much as $400 \mathrm{~mL}$ and soaking for 1 hour. After decolourization was complete, the process continued to the deacetylation stage by adding $400 \mathrm{~mL}$ of $50 \% \mathrm{NaOH}(\mathrm{w} / \mathrm{v})$ and heated at $120{ }^{0} \mathrm{C}$ for 2.5 hours. Chitosan products were washed until neutral and dried. Then it was tested by dissolving the product in $5 \%$ acetic acid $\left(\mathrm{CH}_{3} \mathrm{COOH}\right)$.

Chitosan was characterized by Fourier Transform Infrared (FTIR) spectrophotometer. The yield of each process and the degree of deacetylation (DD) were calculated using the equation (1) and (2) as follow: ${ }^{12,13}$

Yield $=\frac{\text { mass obtained }}{\text { Initial mass }} \times 100 \%$

$\mathrm{DD}=\left[1-\left\{\frac{A 1655}{A 3450} \times \frac{1}{1,33}\right\}\right] \times 100 \%$

where A 1655 is the absorbance of the carbonyl group $(-\mathrm{C}=\mathrm{O})$ at a wavelength of about $1655 \mathrm{~cm}^{-1}$. A 3450 is the absorbance of hydroxyl $(-\mathrm{OH})$ and amine groups $\left(-\mathrm{NH}_{2}\right)$ at a wavelength of about $3450 \mathrm{~cm}^{-1}$. Absorbance was calculated from transmittance $(\% \mathrm{~T})$ value.

\section{Chitosan Application in Wellbore Water}

Wellbore water samples were taken from Gampong Paya Bujok Seuleumak, Kota Langsa. Each sample of $100 \mathrm{~mL}$ wellbore water were transferred into four $500 \mathrm{~mL}$ beakers. Then chitosan was added respectively with a mass of 0 gram, 0.4 gram, 0.8 gram, and 1.2 grams. The mixture was stirred for 25 minutes then left at room temperature for 35 minutes so that the deposition process was complete. After that, supernatant water and precipitate were separated. Supernatant water was taken and each was put into 4 plastic bottles. The $\mathrm{pH}$ value of each water was measured by a $\mathrm{pH}$ meter. The concentration of iron $(\mathrm{Fe})$ and manganese $(\mathrm{Mn})$ from each water sample were measured using an atomic absorption 
spectrophotometer (AAS). Measurements of iron $(\mathrm{Fe})$ and manganese $(\mathrm{Mn})$ from each water sample were carried out 3 times of repetition so that there were 24 measurements. Data of iron $(\mathrm{Fe})$ and manganese $(\mathrm{Mn})$ after treatment with chitosan with several variations of concentration were analyzed using ANOVA at a significance level of 0.05. Duncan's Multiple Range Test (DMRT) was performed to test the real difference.

\section{Result and Discussion}

\section{Isolation and Characterization of Chitosan}

One source of chitosan can be obtained from white shrimp shells (Penaeus merguiensis) taken from household waste. Chitosan isolation consists of several stages, namely deproteination, demineralization and deacetylation. Deproteination process was done by adding $5 \% \mathrm{NaOH}$ solution which aims to remove protein. The protein contained in the shells of white shrimp (Penaeus merguiensis) will dissolve and undergo hydrolysis in the presence of a strong base solution $(\mathrm{NaOH})$. In the process of hydrolysis, the peptide bonds in proteins will experience a breakdown to produce amino acids. After the deproteination process, the shrimp shell powder was washed to a neutral $\mathrm{pH}$ for removing the remaining $\mathrm{NaOH}$ solution.

The process continued to demineralization for removing various minerals contained in shrimp shells. In this process, the solution $\mathrm{HCl}$ was added to the shrimp shell powder resulting in an acidic reaction with minerals and produces gas bubbles in accordance with the following reactions ${ }^{14}$ :

$$
\begin{aligned}
& \mathrm{Ca}_{3}\left(\mathrm{PO}_{4}\right)_{2}(\mathrm{~s})+6 \mathrm{HCl}(\mathrm{aq}) \rightarrow 3 \mathrm{CaCl}_{2}(\mathrm{aq})+2 \mathrm{H}_{3} \mathrm{PO}_{4}(\mathrm{aq}) \\
& \mathrm{CaCO}_{3}(\mathrm{~s})+2 \mathrm{HCl}(\mathrm{aq}) \rightarrow \mathrm{CaCl}_{2}(\mathrm{aq})+\mathrm{CO}_{2}(\mathrm{~g})+\mathrm{H}_{2} \mathrm{O}(\mathrm{aq})
\end{aligned}
$$

In accordance with the reaction above the gas bubbles produced are carbon dioxide $\left(\mathrm{CO}_{2}\right)$. The addition of $\mathrm{HCl}$ was stopped when the mineral salts have finished reacting which was indicated by gas bubbles that were no longer produced. The product after this process (demineralization) was chitin. The chitin obtained was 44.45 grams and its colour was brown so it must be continued by the decolourization process using $\mathrm{NaOCl}$ solution. The results of decolourization obtained white chitin which was insoluble in either $10 \% \mathrm{HCl}$ or $5 \%$ acetic acid. This chitin was deacetylated into chitosan and obtained 17.94 grams of dry white chitosan powder.
The yield of chitosan was $17.73 \%$ and dissolved well in a $5 \%$ acetic acid $\left(\mathrm{CH}_{3} \mathrm{COOH}\right)$ solution. This showed that the transformation of chitin to chitosan was successful. The solubility test to determine the formation of chitosan has been done by adding $5 \% \mathrm{CH}_{3} \mathrm{COOH}$. Chitosan can dissolve well in $5 \%$ acetic acid.

Chitosan was characterized by infrared spectroscopy (FTIR) to determine the value of the degree of deacetylation (DD) and the chemical groups that were characteristic of chitosan. The chitosan structure ${ }^{6}$ and FTIR spectrum can be seen in the following Figure.

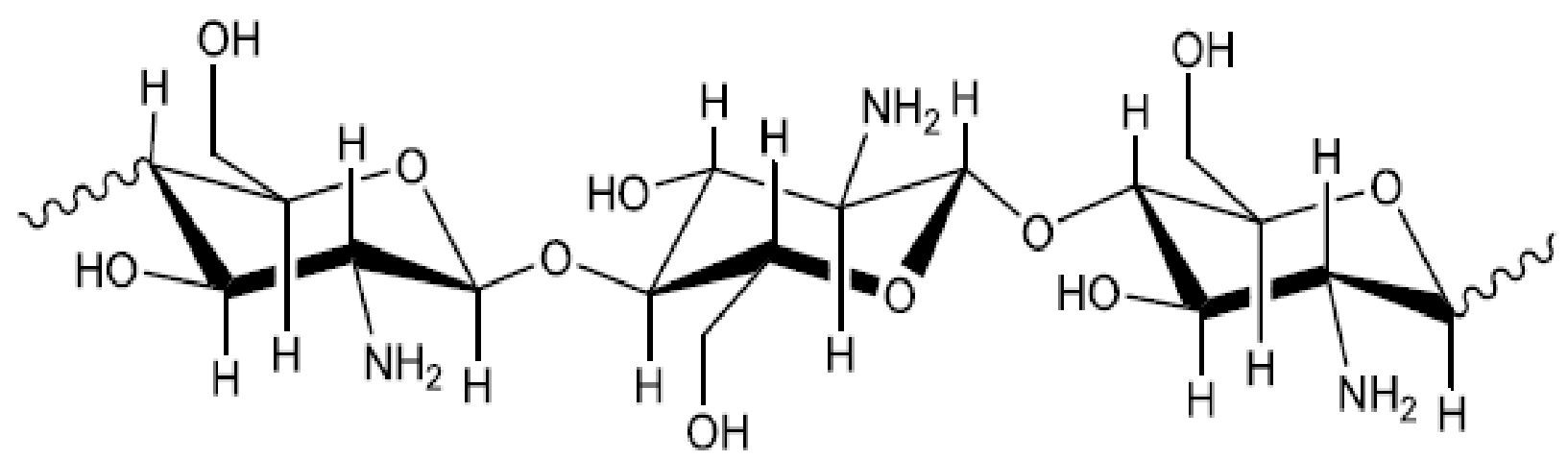

Figure 1. The Structure of Chitosan 


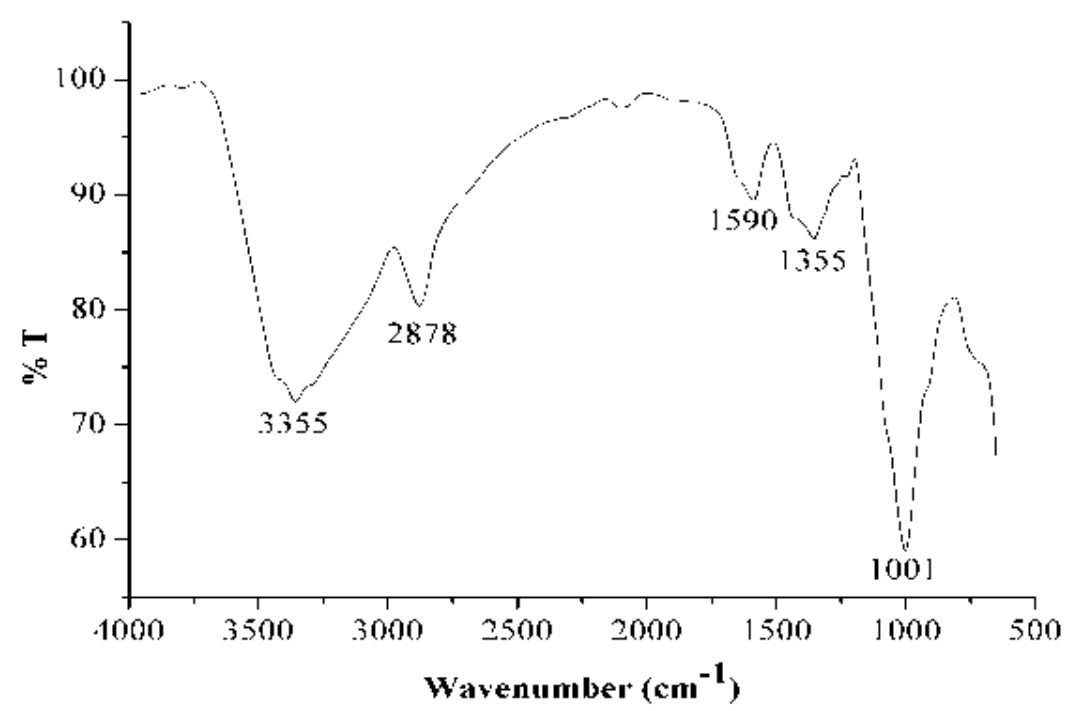

Figure 2. FTIR Spectra of Isolated Chitosan

Based on the above spectrum, there is absorption at the wavenumber $3355 \mathrm{~cm}^{-1}$ with high intensity, which shows the overlapping vibration absorption of the $-\mathrm{OH}$ and $-\mathrm{NH}$ groups. The peak absorption vibration stretching - $\mathrm{CH}$ appears at wavenumber 2878 $\mathrm{cm}^{-1}$ while the bending vibration of $-\mathrm{CH}$ appears at wave number $1355 \mathrm{~cm}^{-1}$. The absorption with high intensity at wave number $1001 \mathrm{~cm}^{-1}$ indicated the existence of stretching vibrations of $\mathrm{C}-\mathrm{O}$. The peak of the carbonyl group $(-\mathrm{C}=\mathrm{O})$ at $1643 \mathrm{~cm}^{-1}$ did not occur because of its small absorption. However, the bending vibration absorption intensity of the free amine group $\left(-\mathrm{NH}_{2}\right)$ at wavenumber 1590 $\mathrm{cm}^{-1}$ increased which showed a high degree of chitosan deacetylation (DDA). ${ }^{13}$ This shows that the deacetylation process was successful. When deacetylation occurs, the absorption intensity of the carbonyl group $(-\mathrm{C}=\mathrm{O})$ at $1643 \mathrm{~cm}^{-1}$ will decrease while the absorption intensity of the free amine group $\left(-\mathrm{NH}_{2}\right)$ at wavenumber $1590 \mathrm{~cm}^{-1}$ will increase. ${ }^{15}$

The degree of deacetylation (DD) of isolated chitosan was $78 \%$. The value of the degree of deacetylation showed that the transformation of shrimp shells into chitosan was successful with the number of acetyl groups $\left(-\mathrm{COCH}_{3}\right)$ lost reaching $78 \%$.
Table 1. Isolation Process of Chitosan

\begin{tabular}{lll}
\hline Process & Yield $\mathbf{( \% )}$ & Colour \\
\hline Deproteination & 76,52 & Brown \\
Demineralization & 57,18 & Brown \\
Decolourization & 93,88 & White \\
Deacetylation & 42,99 & White \\
\hline
\end{tabular}

\section{Chitosan Application in Wellbore Water}

One function of chitosan is as an adsorbent that can absorb metal ions. Isolated chitosan powder was applied to water taken from the wellbore in Gampong Paya Bujok Seuleumak, Kota Langsa. The results of water treatment with chitosan showed no difference in watercolour before and after treatment. This can be caused by low content of iron $(\mathrm{Fe})$ and other metal ions in the water so that it did not really affect on colour change. Besides the use of chitosan in the form of powder which has a small surface area so that the adsorption of metal ions in water is not optimal. However, the $\mathrm{pH}$ value of the water changes after treatment with chitosan as shown in Figure 2. 


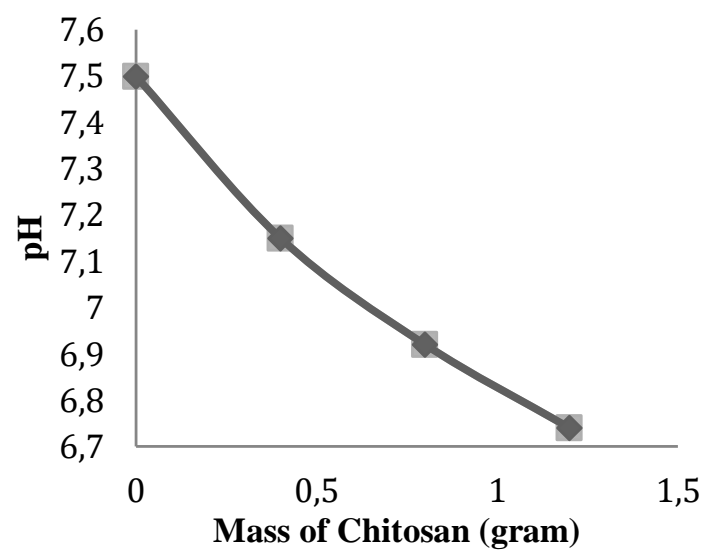

Figure 3. The Effect of Chitosan on $\mathrm{pH}$

From Figure 3 it can be seen that the addition of chitosan can reduce the $\mathrm{pH}$ of water. The $\mathrm{pH}$ value of water will decrease with increasing concentration of chitosan added. This is caused by chitosan acidity and the existence of cationic polyelectrolytes of chitosan. ${ }^{16}$ Suptijah ${ }^{17}$ also argued that chitosan is polycationic. Measurement of iron $(\mathrm{Fe})$ content in water from treatments with various variations of the mass of chitosan was also carried out. The measurement results can be seen in Table 2.

Table 2. The Effect of Chitosan on Content

\begin{tabular}{cc}
\multicolumn{2}{c}{ of Iron (Fe) Ion } \\
\hline $\begin{array}{c}\text { Mass of Chitosan } \\
\text { (gram) }\end{array}$ & Iron (ppm) \\
\hline 0 & $<0,009$ \\
0,4 & $<0,009$ \\
0,8 & $<0,009$ \\
1,2 & $<0,009$ \\
\hline
\end{tabular}

The concentration of iron $(\mathrm{Fe})$ in water without treatment with chitosan was so low that the addition of chitosan in the water had no effect. This means that the adsorption process was not optimum. In addition, adsorption of iron $(\mathrm{Fe})$ ion depends on $\mathrm{pH}$ which iron $(\mathrm{Fe})$ ion adsorption increased at $\mathrm{pH}$ 2.8-4.0. When $\mathrm{pH}>4$ the iron $(\mathrm{Fe})$ ion will more be attracted to hydroxide ion $\left(\mathrm{OH}^{-}\right)$ compared to amine $\left(-\mathrm{NH}_{2}\right)$ group of chitosan. ${ }^{18}$ In this study, adsorption iron $(\mathrm{Fe})$ ion was carried out at $\mathrm{pH}$ water 7.50 that the adsorption condition was not optimum. Different results were shown in the measurement of manganese ion content $(\mathrm{Mn})$ in water as in Table 3.

Table 3. The Effect of Chitosan on Content of Manganese (Mn) Ion

\begin{tabular}{|c|c|}
\hline $\begin{array}{c}\text { Mass of Chitosan } \\
\text { (gram) }\end{array}$ & Mn (ppm) \\
\hline 0 & $0,0312^{\mathrm{a}}$ \\
\hline 0,4 & $0,0301^{\mathrm{b}}$ \\
\hline 0,8 & $0,0156^{\mathrm{c}}$ \\
\hline 1,2 & $0,0034^{\mathrm{d}}$ \\
\hline $\begin{array}{ll}\text { Note: } & \text { the numbers in } \\
& \text { same letter indic } \\
& \text { based on the sm } \\
\text { test at a significa }\end{array}$ & $\begin{array}{l}\text { umn followed by the } \\
\text { significant difference } \\
\text { significant difference } \\
\text { of } 0.05 \text {. }\end{array}$ \\
\hline
\end{tabular}

Based on the results of the analysis of variance (ANOVA), it was known that there was an effect of chitosan with variations in mass on decreasing the content of manganese $(\mathrm{Mn})$ in wellbore water. From Table 3 it can be seen that each treatment had a real difference from the other treatments. This means that the higher the mass of chitosan added, the higher the concentration of manganese ions $(\mathrm{Mn})$ in water will decrease. Decreased content of manganese $(\mathrm{Mn})$ in water due to the adsorption of manganese (Mn) ions by adding chitosan powder. Chitosan itself has a structure that contains active sites such as amine groups $\left(-\mathrm{NH}_{2}\right)$ and hydroxyl groups $(-\mathrm{OH})$ that allow the binding of metal ions such as $\mathrm{Mn}^{2+}$ with these groups.

\section{Conclusion}

Chitosan was successfully isolated from white shrimp shells with a degree of 
deacetylation (DD) of $78 \%$. Chitosan had no effect on iron (Fe) content because of its low concentration in wellbore water. Chitosan functions as an adsorbent because it can reduce the concentration of manganese $(\mathrm{Mn})$ ion in wellbore water. The effective mass of chitosan in this study to reduce manganese concentration $(\mathrm{Mn})$ ion in wellbore water was 1.2 grams.

\section{Acknowledgement}

We want to thank Samudra University, especially LPPM Samudra University who had funded this research through the grant of Penelitian Dosen Muda (PDM) 2018.

\section{References}

1. Majekodunmi SO, Olorunsola EO, Ofiwe UC, Udobre AS, Akpan E. Material properties of chitosan from shells of Egeria radiata: Drug delivery considerations. Journal of coastal life medicine. 2017; 5(7): 21-324.

2. Hou Y, Shavandi A, Carne A, Bekhit A.A, Ng TB, Cheung RCF, Bekhit AEA. Marine shells: Potential opportunities for extraction of functional and healthpromoting materials. Critical Reviews in Environmental Science and Technology. 2016; 46 (11-12): 1047-1116

3. Sinardi, Soewondo P, Notodarmojo S. Pembuatan, karakterisasi dan aplikasi kitosan dari cangkang kerang hijau (Mytulus virdis linneaus) sebagai koagulan penjernih air. Konferensi Nasional Teknik Sipil (KoNTeks 7); 2426 Oktober 2013; Surakarta; Universitas Sebelas Maret; 2013. P.33-38.

4. Hamid M. PDAM kota langsa lebih reaktif terhadap masalah air bersih [Internet]. 2017 [cited 2018 Feb 22]. Available from: http://humas.setda.langsakota.go.id/pda m-kota-langsa-lebih-reaktif-terhadapmasalah-air-bersih2017

5. Said NI. Pembuatan filter untuk menghilangkan zat besi dan mangan dalam air [Internet]. 2018 [cited 2018 Feb 22]. Available from:
http://www.kelair.bppt.go.id/Sitpa/Artik el/Filter/filter.html

6. Kumari S, Rath P, Kumar ASH, Tiwari TN. Extraction and characterization of chitin and chitosan from fishery waste by chemical method. Environmental Technology \& Innovation. 2015; 3(2015): 77-85

7. Arbia W, Arbia L, Adour L, Amrane A. Chitin recovery using biological methods. Food Technol. Biotechnol. 2013; 51 (1): 12-25

8. Sjaifullah A, Santoso AB. Autolytic isolation of chitin from white shrimp (Penaues vannamei) waste. Procedia Chemistry. 2016; 18 (2016): 49 - 52

9. Al-Manhel AJ, Al-Hilphy ARS, Niamah AK. Extraction of chitosan, characterization and its use for water purification. Journal of the Saudi Society of Agricultural Sciences. (2016):1-4

10. El Knidri H, El Khalfaouy R, Laajeb A, Addaou A, Lahsini A. Eco-friendly extraction and characterization of chitin and chitosan from the shrimp shellwaste via microwave irradiation. Process Safety and Environment Protection. 2016; 104 (Part A): 395-405

11. Samar MM, El-Kalyoubi MH, Khalaf MM, El-Razik MMA. Physicochemical, functional, antioxidant and antibacterial properties of chitosan extracted from shrimp wastes by microwave technique. Annals of Agricultural Science. 2013: 58(1): 33-41

12. Majekodunmi SO, Olorunsola EO, Uzoaganobi CC. Comparative physicochemical characterization of chitosan from shells of two bivalved mollusks from two different continents. American Journal of Polymer Science. 2017; 7(1): 15-22

13. He X, Li K, Xing R, Liu S, Hu L, Li P. The production of fully deacetylated chitosan by compression method. Egyptian Journal of Aquatic Research. 2016; 7(1): 15-22

14. Kurniasih M, Kartika D. Sintesis dan karakterisasi fisika-kimia kitosan. Jurnal Inovasi. $2011 ; 5(1)$ : 42-48 
15. Kumari S, Rath PK. Extraction and characterization of chitin and chitosan from (Labeo rohit) fish scales. Procedia Materials Science. 2014; 6(2014): 482489

16. Hendrawati, Sumarni S, Nurhasni. Penggunaan kitosan sebagai koagulan alami dalam perbaikan kualitas air danau. Jurnal KIMIA VALENSI: Jurnal Penelitian dan Pengembangan Ilmu Kimia. Mei 2015; 1(1): 1-11
17. Suptijah P, Zahiruddin W, Firdaus D. Pemurnian air sumur dengan kitosan melalui tahapan koagulasi dan filtrasi. Buletin Teknologi dan Hasil Perikanan. 2008; 11(1): 65-75

18. Prambaningrum W, Djunaidi MC. Adsorpsi ion besi (III) dan cadmium (II) menggunakan gel kitosan. Jurnal Kimia Sains dan Aplikasi. 2009; 12 (2) : 47-51 